KONSTRUKTIVISME, Vol. 8, No. 1, Januari 2016

p-ISSN: 1979-9438, e-ISSN: 2445-2355

FKIP Universitas Islam Balitar, Blitar

Web: konstruktivisme.unisbablitar.ejournal.web.id

\title{
PENERAPAN INKUIRI TERBIMBING PADA HASIL BELAJAR KOGNITIF SISWA KELAS VII A SMPN 3 TANJUNG DALAM KONSEP EKOSISTEM
}

\author{
Almira Ulimaz \\ Program Studi Pendidikan Biologi \\ STKIP PGRI BANJARMASIN \\ Jl. Sultan Adam Komplek Haji lyus No. 18 RT 23 Telp. 0511-4315443 \\ Banjarmasin, Kalimantan Selatan \\ e-mail: almiraulimaz2521988@gmail.com
}

\begin{abstract}
This study is aimed at seeing how process of improvement of cognitive learning achievement on ecosystem instruction using guided inquiry model. This study used Classroom Action Research with two cycles conducted in four meetings. The subject of the study was the 20 students of grade VII of SMPN 3 Tanjung, South Kalimantan. Data were collected using test and scores of pretest and posttest were used for analysis. Data were analyzed both in quantitative and qualitative forms. The study revealed that guided inquiry model improves cognitive achievement of the VII graders of SMPN Tanjung.
\end{abstract}

Keywords: inquiry, ecosystem, cognitive.

\begin{abstract}
Abstrak
Penelitian ini bertujuan untuk melihat proses peningkatan hasil belajar kognitif produk siswa terhadap pembelajaran ekosistem menggunakan model inkuiri terbimbing. Metode yang digunakan adalah PTK (Penelitian Tindakan Kelas) yang terdiri dari 2 siklus dengan 4 kali pertemuan. Subjek penelitian adalah siswa kelas VII A SMPN 3 Tanjung yang berjumlah 20 orang. Teknik pengumpulan data menggunakan hasil pretes dan posttest siswa. Teknik analisis data yang digunakan adalah kualitatif dan kuantitatif. Hasil penelitian menunjukkan bahwa pembelajaran menggunakan inkuiri terbimbing dapat meningkatkan hasil belajar kognitif produk siswa kelas VII A SMPN 3 Tanjung.
\end{abstract}

Kata kunci: Ekosistem, hasil belajar, inkuiri terbimbing.

Undang-Undang No. 20 Tahun 2003 tentang Sistem Pendidikan Nasional menyatakan bahwa pendidikan adalah usaha sadar dan terencana untuk mewujudkan suasana belajar dan proses pembelajaran agar peserta didik secara aktif mengembangkan potensi dirinya untuk memiliki kekuatan spiritual keagamaan, pengendalian diri, kepribadian, 
Ulimaz, Almira. 2016. Penerapan Inkuiri Terbimbing pada Hasil Belajar

kecerdasan, akhlak mulia, serta keterampilan yang diperlukan dirinya, masyarakat, bangsa, dan negara (Sanjaya, 2012:2). Dalam keseluruhan proses pendidikan di sekolah, kegiatan belajar merupakan kegiatan yang paling pokok. Berarti, bahwa berhasil tidaknya pencapaian tujuan pendidikan banyak bergantung kepada bagaimana proses belajar yang dialami oleh siswa sebagai anak didik (Daryanto, 2009:1).

Berdasarkan hasil wawancara dengan guru IPA kelas VII A SMPN 3 Tanjung diketahui bahwa hasil belajar siswa kelas VII A khususnya pada konsep ekosistem masih tergolong rendah. Hal ini dapat dilihat dari hasil ulangan harian di tahun ajaran 2013/2014 yaitu hanya 53,85\% ketuntasan klasikal siswa yang mencapai KKM sebesar 65 . Hasil belajar tersebut tentu belum maksimal karena masih di bawah ketuntasan secara klasikal yang ditetapkan yaitu sebesar $85 \%$. Sekarang ini nilai ketuntasan pembelajaran di SMPN 3 Tanjung di tahun ajaran 2014/2015 ditingkatkan menjadi 70, inilah yang nantinya akan dijadikan sebagai salah satu indikator keberhasilan kegiatan belajar siswa.

Pemahaman siswa terhadap materi ekosistem belum optimal karena guru mengajar hanya menggunakan metode ceramah, dan penugasan. Siswa hanya mendengarkan dan menulis apa yang disampaikan oleh guru sehingga siswa pasif, dan kurang termotivasi dalam mengikuti pelajaran. Untuk itu perlu alternatif pembelajaran yang dapat membuat siswa lebih tertarik, aktif dan kreatif dalam proses pembelajaran, serta dapat memperbaiki proses, dan meningkatkan hasil belajar siswa. Salah satu model pembelajaran yang tepat untuk diterapkan dalam pembelajaran adalah model pembelajaran inkuiri terbimbing.

Inkuiri terbimbing adalah pelaksanaan inkuiri dilakukan atas petunjuk dan bimbingan guru, sehingga siswa mampu memahami konsep pelajaran (Putra, 2013:96). Kegiatan belajar mengajar ini dapat mengembangkan keterampilan berpikir kritis. Pendekatan ini juga melatih siswa untuk berpikir, memecahkan masalah, dan menemukan, siswa memiliki kesempatan untuk belajar dan berlatih merancang percobaan dan merekam data, serta dapat membantu siswa menjadi mandiri, percaya diri dan yakin pada kemampuan intelektualnya sendiri untuk terlibat aktif (Suprihatiningrum, 2012).

\section{METODE}

Penelitian ini merupakan Penelitian Tindakan Kelas (PTK) yang terdiri dari 2 siklus dengan 4 kali pertemuan. Masing-masing siklus terdiri dari perencanaan (planning), pelaksanaan tindakan (action), pengamatan (observation), dan refleksi (reflection). Penelitian ini dilaksanakan di SMPN 3 Tanjung pada kelas VII A. Subjek penelitian ini adalah seluruh siswa kelas VII A SMPN 3 Tanjung dengan jumlah siswa sebanyak 20 orang yang terdiri dari siswa laki-laki 10 orang dan siswa perempuan 10 orang. Adapun waktu penelitian dilaksanakan dari bulan Maret sampai Juli 2015 pada semester 2 (dua) Tahun Ajaran 2014/2015.

Pengumpulan data dilakukan dengan teknik tes yang tercermin dari instrumen penelitian seperti pada Tabel 1. berikut ini. 
FKIP Universitas Islam Balitar, Blitar

Web: konstruktivisme.unisbablitar.ejournal.web.id

Tabel 1 Instrumen Penelitian

\begin{tabular}{cccc}
\hline $\begin{array}{c}\text { Jenis } \\
\text { data }\end{array}$ & $\begin{array}{c}\text { Sumber } \\
\text { data }\end{array}$ & \multicolumn{1}{c}{ Instrumen data } \\
\hline $\begin{array}{l}\text { Hasil } \\
\text { belajar }\end{array}$ & $\begin{array}{l}\text { Siswa, } \\
\text { guru }\end{array}$ & $\begin{array}{l}\text { 1. Tes (pretest dan postest) hasil belajar ranah } \\
\text { kognitif produk dan kognitif proses }\end{array}$ \\
produk & $\begin{array}{l}\text { model, } \\
\text { dan } \\
\text { observer }\end{array}$ & $\begin{array}{l}\text { 2. Lembar observasi/pengamatan psikomotor } \\
\text { 3. Lembar observasi/pengamatan afektif (perilaku } \\
\text { berkarakter dan keterampilan sosial) }\end{array}$ \\
\hline
\end{tabular}

Analisis data yang digunakan dalam penelitian ini adalah analisis data kualitatif dan analisis data kuantitatif. Data kualitatif dilakukan secara deskriptif. Data kuantitatif berupa data hasil belajar kognitif produk siswa.

\section{HASIL}

\section{Hasil Belajar Ranah Kognitif Produk}

Data hasil belajar siswa ranah kognitif yang diperoleh dari nilai pretest dan postest dapat dilihat pada Tabel 2.

Tabel 2. Hasil Belajar Siswa Ranah Kognitif

\begin{tabular}{ccccc}
\hline \multirow{2}{*}{ Ketuntasan } & \multicolumn{2}{c}{ Siklus I } & \multicolumn{2}{c}{ Siklus II } \\
\cline { 2 - 5 } klasikal & Pertemuan & Pertemuan & Pertemuan & Pertemuan 2 \\
Pretest & 1 & 2 & 1 & $25 \%$ \\
Postest & $15 \%$ & $20 \%$ & $20 \%$ & $95 \%$ \\
\hline
\end{tabular}

\section{BAHASAN}

Hasil belajar siswa ranah kognitif produk pada siklus I diperoleh dari nilai pretest dan postest. Dari Tabel 2 terlihat hasil pretest pertemuan 1 ketuntasan klasikal hanya mencapai $15 \%$. Hal ini membuktikan bahwa konsep ekosistem yang disajikan belum dikuasai oleh siswa, setelah diadakan pembelajaran dengan menggunakan inkuiri terbimbing ketuntasan klasikal meningkat dengan persentase sebesar $60 \%$.

Ketuntasan klasikal pada siklus I pertemuan 2 adalah sebesar $20 \%$ pada pretest meningkat menjadi $75 \%$ pada postest. Hal ini menunjukkan bahwa ketuntasan belajar siswa belum mencapai target ketuntasan klasikal yaitu sebesar $85 \%$. Diduga hal ini dikarenakan sintaks pembelajaran inkuiri terbimbing belum sepenuhnya dilaksanakan secara efisien dan efektif oleh guru. Siswa belum terbiasa dengan dengan model pembelajaran baru yang diberikan oleh guru membuat siswa kebinggungan dengan apa yang harus dilakukannya sehingga siswa masih belum mampu menemukan sendiri pengetahuan yang ingin didapatnya. Hal tersebut akan menjadi bahan perbaikan pada siklus berikutnya.

Ketuntasan klasikal pada siklus II mengalami peningkatan. Pada pertemuan 1 hasil pretest perolehan ketuntasan klasikal sebesar 20\% dan meningkat pada hasil postest dengan ketuntasan klasikal sebesar $85 \%$. 
Ulimaz, Almira. 2016. Penerapan Inkuiri Terbimbing pada Hasil Belajar Kognitif Siswa Kelas VII A SMPN 3 Tanjung dalam Konsep Ekosistem.

Konstruktivisme, 8(1): 96-100.

Pada pertemuan 2 hasil pretest perolehan ketuntasan klasikal sebesar $25 \%$ dan meningkat dari sebelumnya menjadi 95\%. Berdasarkan hasil tersebut maka penelitian terhadap hasil belajar siswa ranah kognitif dapat dikatakan berhasil karena pada siklus II pertemuan 1 dan 2 hasil postest siswa telah mencapai indikator keberhasilan secara klasikal yaitu $85 \%$ sehingga peneliti tidak perlu lagi melakukan tindakan/siklus berikutnya karena penelitian ini sudah dapat dikatakan berhasil.

Peningkatan ketuntasan klasikal tersebut dikarenakan pada siklus II guru telah melaksanakan pembelajaran yang telah disusun sesuai dengan RPP yang dibuat oleh peneliti. Siswa sudah terbiasa dengan pembelajaran inkuiri terbimbing sehingga siswa mampu melakukan kegiatan atau aktivitas mencari dan menemukan jawaban atau pemecahan masalah sendiri, dan dapat dikatakan pembelajaran sudah berfokus pada siswa.

Berdasarkan uraian tersebut sejalan dengan hasil penelitian Schlenker, dalam Joyce dan Weil (1992:198) seperti dikutip Trianto (2012:167) menunjukkan bahwa latihan inkuiri dapat meningkatkan pemahaman sains, produktif dalam berpikir kreatif, dan siswa menjadi terampil dalam memperoleh dan menganalisis informasi. Hasil penelitian lain yang juga sejalan dengan penelitian ini yaitu Norminawati (2014). Hasil penelitiannya menunjukkan bahwa dengan menggunakan model pembelajaran inkuiri terbimbing dapat meningkatkan hasil belajar siswa.

\section{SIMPULAN}

Berdasarkan hasil penelitian dan pembahasan, maka dapat disimpulkan bahwa dengan menggunakan model pembelajaran inkuiri terbimbing pada kegiatan belajar mengajar dapat meningkatkan hasil belajar siswa kelas VII A SMPN 3 Tanjung pada ranah kognitif produk.

\section{SARAN}

Berdasarkan hasil penelitian seperti yang disimpulkan di atas, maka disarankan sebagai berikut. (1) Guru bidang studi IPA (Biologi) dapat menggunakan model pembelajaran inkuiri sebagai alternatif dalam melaksanakan pembelajaran, khususnya pada konsep ekosistem dan materi lainnya agar siswa lebih termotivasi mengikuti pelajaran dan dapat meningkatkan hasil belajar siswa; (2) Bagi pembaca yang ingin mengadakan penelitian dengan menggunakan inkuiri terbimbing ini perlu melakukannya pada materi pelajaran yang lain, agar semangat siswa dalam belajar dan mengikuti pembelajaran akan lebih meningkat.

\section{DAFTAR PUSTAKA}

Daryanto. 2009. Panduan Proses Pembelajaran Kreatif dan Inovatif. Jakarta: AV Publisher.

Norminawati. 2014. Upaya Meningkatkan Hasil Belajar Siswa Kelas VII A SMPN 2 Kusan Hilir pada Konsep Ekosistem dengan Menggunakan Model Pembelajaran Inkuiri Terbimbing. Skripsi tidak dipublikasikan. Banjarmasin: STKIP PGRI. 
Putra, Sitiatava Rizema. 2013. Desain Belajar Mengajar Kreatif Berbasis Sains. Jogjakarta: Diva Press.

Sanjaya, Wina. 2012. Strategi Pembelajaran Berorientasi Standar Proses Pendidikan. Jakarta: Kencana.

Suprihatiningrum, Jamil. 2012. Strategi Pembelajaran. Jogjakarta: Ar-Ruzz Media.

Trianto, 2012. Mendesain Model Pembelajaran Inovatif - Progresif Konsep, Landasan, dan Implementasinya Pada Kurikulum Tingkat Satuan Pendidikan (KTSP). Jakarta: Kencana Prenada Media Group. 